\section{The effect of magnesium pemoline. tric yanoaminopropene. and d-amphetamine on discriminated avoidance performance in rats as a function of age*}

\author{
W. JOSEPH POTTS $\div$ DAVID L. MORSE, $\div \div$ \\ BARRETT R. COOPER, and WILLIAM C. BLACK \\ Purdue University, Lafayette, Ind. 47907
}

The effects of magnesium pemoline, tricyanoaminopropene, and d-amphetamine on the acquisition of a discriminated avoidance response were compared in 30-, 50-, and 100-day-old naive rats. The rats were placed in an automated shuttlebox immediately after drug treatment. The number of avoidance responses in a series of 100 trials was measured. Ten days after the initial acquisition session. the rats were retrained on the same tisk. The 30-day group was inferior to the 50- and 100-day groups in the training session, but no differences occurred in retraining. I ? drug-treated groups showed improved performance in the initial training session bu were not different from the controls in the retraining session. No Drug by Age interaction was significant.

Studies that have utilized shock as the unconditioned stimulus (UCS) and a discrete conditioned stimulus (CS) have generally shown that magnesium pemoline has a facilitatory effect on learning (Plotnikoff, 1966a, b, c, 1967; Kulkarni, 1967; Howard \& Doty, 1967; Filby et al, 1967; and Ritzmann et al, 1969). Other investigators who have used a discrete CS and shock as the UCS have suggested that the altered behavior was not due to learning but was due to the stimulant action of the drug (Frey \& Polidora, 1967; Beach \& Kimble, 1967; Chase \& Rescorla, 1968; Soumireu-Mourat \& Cardo, 1968; and Powell et al, 1967a, b).

Gerard et al (1963) demonstrated that tricyanoaminopropene (triap) decreased fixation time of a postural asymmetry of the hind legs in rats when the cerebellum was unilaterally lesioned. Chamberlin et al (1963) showed it improved barpress avoidance in rats but had no effect on Hebb-Williams maze performance. Essman (1967) injected mice chronically from 3 to 16 days of age. He tested the animals at 25 days in a water maze and found facilitation of an escape response from the maze, such that they showed a decreased latency and a greater incidence of errorless performance. Essman (1966) and Essman $\&$ Golod (1968) pretreated mice for 3 days prior to a single passive-avoidance trial that

*This investigation was supported in part by grants from the National Institute of Yental Health, I F1-MH 30331 and $\mathrm{MH} \mathrm{14156-01.}$

$\div W$. Joseph Potts's present address: Department of Pharmacology, G. D. Searle \&

Co.. P.O. Box 5110 , Chicago. Illinois 60680 .

$\div$ David L. Morse's present aldress: Department of Psychology. State College. New Paltz. New York 12561. was followed by electroconvulsive shock. When tested for retention $24 \mathrm{~h}$ later, characteristic retrograde amnesia was demonstrated in controls, but the triap-treated animals showed significant retention.

Brush et al (1966) and McNutt (1967) found that triap did not facilitate learning significantly in maze and avoidance situations. Gurowitz et al (1968) demonstrated that triap had a detrimental dose-related effect on passive-avoidance performance in rats.

Studies utilizing d-amphetamine in shock-avoidance paradigms indicated that this compound facilitated performance by reducing the freezing behavior (Krieckhaus et al, 1965, Hearst \& Whalen, 1963 .)

The studies concerning the effects of drugs on learning have mostly utilized adult $\mathrm{Ss}$, and, until this time, no experiments have evaluated the effects of these drugs on learning as a function of age. Since drugs are known to have differential effects on avoidance conditioning in rats of different ages (Doty \& Doty. 1964), it was postulated that magnesium pemoline, triap, or d-amphetamine might show differential effects during the aging process. The present study was carried out to evaluate the effects of magnesium pemoline, triap, and d-amphetamine on learning and memory in rats of various ages in the shuttlebox avoidance paradigm.

\section{METHODS}

Ninety-six male hooded rats of the Long-Evans strain served as Ss. One-third of the animals were 28.33 days old, one-third were 47.53 days old, and one-third were 96-105 days old at the initiation of the experiment. Within each age group rats were assigned randomly to each drug treatment group. All animals were raised in a continuously lighted environment from time of birth.

Testing was done in an automated two-compartment shuttlebox (Lafayette Instrument Company, Model A-580) with a motor-driven guillotine door separating the two chambers. The shuttlebox was enclosed in a darkened sound-attenuating chamber. Individual light sources in the ceiling of each chamber served as the CS. A constant-current shocker delivered 0.4-mA current to the grid floor of the shuttlebox. A photocell sensing system was used to detect the presence of the rat in either compartment of the shuttlebox. The responses were scored automatically and printed on a print counter.

All drugs were suspended in $0.3 \%$ tragacanth. Injections of $10 \mathrm{mg} / \mathrm{kg}$ magnesium pemoline, $15 \mathrm{mg} / \mathrm{kg}$ triap, $0.75 \mathrm{mg} / \mathrm{kg}$ d-amphetamine, or a control volume of $0.3 \%$ tragacanth were given intraperitoneally $30 \mathrm{~min}$ prior to testing. The rat was then transferred from his home cage into one compartment of the shuttlebox. He was allowed to remain in the compartment approximately $1 \mathrm{~min}$ before the first trial was initiated. The onset of light in the ceiling of the compartment in which the animal was present and the simultaneous raising of the guillotine door served as the CS. The light alone was on for $10 \mathrm{sec}$, at which time the UCS, consisting of the $0.4-\mathrm{mA}$ shock also occurred. The safe side of the shuttlebox was dark and not energized. When the animal entered the safe side of the shuttlebox, the guillotine door closed, the trial was terminated, and a $30-\mathrm{sec}$ intertrial interval was initiated. An avoidance was scored when the rat moved to the safe side during the CS interval and before the UCS occurred. An escape was scored when the rat moved to the safe side after receiving the grid shock (i.e., after the UCS onset). The rats received 100 trials (training session) and the number of avoidances was scored. They were then removed and returned to their home cages. The rats were retested (retraining session) 10 days after the initial training for an additional 100 trials. The animals were injected only prior to the training session.

\section{RESULTS}

A two-factor analysis of variance was carried out on the number of avoidance responses made during the 100-trial training session. The age effect was statistically significant $\quad(F=4.81$, $\mathrm{df}=2 / 84, \mathrm{p}<.01)$. The drug effect was also statistically significant $(F=10.37$. $\mathrm{df}=3 / 84, \quad \mathrm{p}<.01)$. The Age by Drug interaction was not statistically significant.

The effects of the drugs on performance 
Table 1

Mean and Standard Error for the Number of Avoidance Responses for the Training and Retraining Sessions in the 100-Trial Shuttlebox Task Summarized Across Drug Groups

\begin{tabular}{lccccc}
\hline & \multicolumn{2}{c}{ Training } & & \multicolumn{2}{c}{ Retraining } \\
\cline { 6 - 7 } $\begin{array}{l}\text { Drug Treatment } \\
\text { Condition }\end{array}$ & II & SE & & M & SE \\
\hline Control & 16.8 & 6.2 & 52.4 & 11.37 \\
$\begin{array}{l}\text { Magnesium } \\
\quad \text { Pemoline }\end{array}$ & $42.1^{\mathrm{a}}$ & 10.5 & 65.1 & 10.0 \\
$\begin{array}{l}\text { Triap } \\
\text { d-Amphetamine }\end{array}$ & $56.8^{\mathrm{a}}$ & 11.51 & 63.4 & 11.0 \\
\hline
\end{tabular}

a Significantly different from the control at .01 level.

of all age groups is summarized in Table 1 . In the training session all drug-treated groups avoided shock more than the control group, but only the magnesium pemoline and d-amphetamine groups had significantly more avoidance responses $(F=11.2, \quad \mathrm{df}=1 / 84, \mathrm{p}<.01 ; \quad \mathrm{F}=27.9$, $\mathrm{df}=1 / 84, \mathrm{p}<.01)$. All age groups showed similar response profiles to the drugs. None of the drug effects were permanent, as shown by the retraining results. In retraining, as in training, each age group showed very similar response patterns within each drug treatment.

The effects of age on performance are shown in Table 2. In the training session the 30-day group avoided significantly fewer times than either the 50 - or 100-day groups, which were not significantly different from each other. In the retraining session the age groups did not differ from each other. It is of interest that the 50-day groups were consistently, though not statistically, superior to both the 30-day and the 100-day groups in the retraining sessions, regardless of the drug treatment prior to the training session.

\section{DISCUSSION}

The results demonstrate that both magnesium pemoline and d-amphetamine facilitated performance in the training session when compared to the relatively poor performance of the control rats. The retraining results showed that the drug effects exerted in the training session were not sustained over the 10-day interval between the two sessions. The temporary effects of these drugs argue against the concept of learning enhancement and argue for performance enhancement. These results tend to substantiate previous findings (Kriekhaus et al, 1965; Hearst \& Whalen, 1963) that low doses of d-amphetamine improved avoidance performance.

The finding that magnesium pemoline's effect was similar to that of d-amphetamine tends to differ from the results reported by Plotnikoff (1966b) that the effect of magnesium pemoline differed
Table 2

Mean and Standard Errors for the Number of Avoidance Responses for the Training and Retraining Sessions in the 100-Trial Shuttlebox Task Summarized Across Age Groups

\begin{tabular}{ccrrrr} 
& \multicolumn{2}{c}{ Training } & & \multicolumn{2}{c}{ Retraining } \\
\cline { 2 - 3 } \cline { 5 - 6 } Age Group & $\mathrm{M}$ & $\mathrm{SE}$ & & $\mathrm{M}$ & $\mathrm{SE}$ \\
\hline 30 Days & 24.4 & 9.3 & & 55.8 & 11.6 \\
50 Days & $42.5^{\mathrm{a}}$ & 10.7 & & 69.8 & 9.8 \\
100 Days & $41.5^{\mathrm{a}}$ & 11.3 & & 58.3 & 10.6 \\
\hline
\end{tabular}

a Significantly different from 30-day group at .05 level by Newman-Keuls comparison.

from that of methamphetamine in a jump-out avoidance task. These opposing results could be explained by strain differences, task differences, or drug congener differences. However, Cooper et al (1969) demonstrated that certain doses of both magnesium pemoline and caffeine enhanced performance in the T-maze. The results of the present studies and those of Cooper et al (1969) argue for the proposition that magnesium pemoline's effect on learning was due only to its CNS stimulant action.

The results concerning the effect of triap on learning and memory tend to substantiate the findings reported by Brush et al (1966), McNutt (1967), and Gurowitz et al (1968) that triap is not effective as a learning enhancer. At the same time, however, these results do not necessarily oppose those reported by Essman (1966, 1967), as he used mice, gave repeated injections of triap, and used different behavioral tasks.

Doty \& Doty (1964) showed that memory consolidation is significantly longer in 30-day rats than in adult rats. On this basis one would expect the 30 -day rats in this study to be the most improved if any of the drug regimens resulted in accelerating consolidation time. However, the drugs had similar effects on all three age groups, indicating the drugs were not acting directly on the learning-memory process but rather on some aspect of performance that was equally distributed across all three age groups.

The evidence that these drugs were acting only by improving performance, as contrasted to true changes in learning, was demonstrated in two ways: the observation that the drug effects were not permanent, was shown by the retraining session results, and the observation that no Age by Drug interaction occurred, even though the behavioral task differentiated 30-day from 50- and 100-day rats.

\section{REFERENCES}

BEACH, G., \& KIMBLE, D. Activits and responsivity in rats after magnesium pemoline injections. Science, $1967,155,698-701$

BRLSH, F., DAVENPORT, J., \& POLIDORA, V.
ICAP: Vegative results in avoidance and water maze learning and retention. Psychonomic Science, $1966,4,183-184$

CHAMBERLIN. T.. ROTHSCHILD. G.. \& GERARD, R. Drugs affecting RVA and learning. Proceedings of the Sational Academy of Science, 1963,49.918-924.

CHASE, T., \& RESCORLA, R. The effect of magnesium pemoline on learning an active avoidance-passive avoidance discrimination. Psychonomic Science. 1968, 10,87-88.

COOPER, B., POTTS. W. J.. MIORSE, D.. \& BLACK, W. The effects of magnesium pemoline, caffeine, and picrotoxin on a food reinforced discrimination task. Psychonomic Science, 1969,14,225-226.

DOTY, B., \& DOTY, L. Effect of age and chlorpromazine on memory consolidation. Journal of Comparative \& Physiological Psychology, 1964, 57, 331-334.

E S S A N, W. The effect of tricyanoaminopropene on the amnesiac effect of electroconvulsive shock. Psychopharmacologia, 1966. 9, 426-433.

ESSMAN, W. Facilitation of maze acquisition by mice with tricyanoaminopropene (TCAP) given during early postnatal development. Psychonomic Science, 1967, 9, 51-52.

ESSMAN, W., \& GOLOD, M. Reduction of retrograde amnesia by tricyanoaminopropene-drug dosage and electroshock intensity. Communications in Behavioral Biology, 1968, 1, 183-187.

FILBY, T., SZARA, S., \& SALZMAN, B. Magnesium pemoline: Effect on acquisition and retention of discriminated avoidance behavior. Psychonomic Science, 1967, 9 , 131-132.

FREY, P., \& POLIDORA, V. Hagnesium pemoline: Effect on avoidance conditioning in rats. Science, $1967,155,1281-1282$.

GERARD, R., CHAMBERLIN, T.. \& ROTHSCHILD, G. RNA in learning and memory. Science, 1963, 140, 381.

GUROWTTZ, E., GROSS, D., \& GEORGE, R. Effect of TCAP on passive avoidance leaming in the rat. Psychonomic Science, 1968, 12, 293-294.

HEARST, E., \& WHALEN, R. Facilitating effects of d-amphetamine on discriminated-avoidance performance. Journal of Comparative \& Physiological Psychology, 1963, 56, 124-128.

HOWARD, S., \& DOTY, B. Facilitative effects of post-trial magnesium pemoline on avoidance conditioning in relation to problem difficulty. Paper read at Midwest Psychological Association meeting, 1967.

KRIECKHALS, E., MILLER, ‥, \& ZIMMERMAN, P. Reduction of freezing behavior and improvement of shock avoidance by d-amphetamine. Journal of Comparative \& Physiological Psychology, 1965, 60, 36-40.

KLLKARYI, A. Magnesium pemoline: Facilitation of instrumental avoidance learning. Psychonomic Science, 1967, 9, 39.40 .

McNLTT, L. 1,1,3-tricyano-2-amino-1-propene A pharmacological attempt to enhance learning ability. Proceedings of the 75 th Annual Convention of the American Psychological Association, 1967, 77-78.

PLOTNIKOFF, N. Magnesium pemoline Antagonism of retrograde amnesia in rats. Federation Proceedings, 1966a. 25. 262.

PLOTNIKOFF, N. Magnesium pemoline: Enhancement of learning and memory of a conditioned avoidance response. Science. 1966b, 151, 703.704.

PLOTNIKOFF, $\quad \therefore$. Magnesium pemoline: Fn hancement of memory after 
clectroconvulsive shock in rats. Life Sciences. 1966c. 5. 1495-1498.

PLOTXIKOFl. $\therefore$. Pemoline and magnesium hydroxide: Momory consolidation following acquisition trials. Psychonomic Science. 1967. 9. $141 \cdot 142$.

POWELL. B., MARTIN, L., \& KAMANO. D. Magnesium pemoline: Effects of training vs testing of an aroidance response. Psychonomic Science. 1967a. 8. 205-206

POWILL, B., MARTIN, L., \& KAUANO, D. More on magnesium pemoline: Differential effects of advance and immediate injections on avoidance perfomance. Prichonomic Science. 1967b. 8. 303-304.

RITZMANN. R.. MILLIR. L.. \& BELL. R. Effects of magnesium pemoline on avoidance behavior in rats. Psychonomic Science. 1969. 14, 103-105.

SOLMIREL-MOLRAT, B., \& CARDO, B. Activity and learning in rats after magnesium pemoline. Psychopharmacologia, 1968, 12, 258-262.

\title{
Reinforcement and response factors in the extinction of conditioned suppression*
}

\author{
RONALD P. BYRUM and DONALD E. JACKSON \\ Eastern Michigan University, Ypsilanti, Mich. 48197
}

Following CER training, 32 rats began initial CER extinction under: (1) normal (lever present), (2)yoked with normals (lever absent), (3) nonoperative lever, or (4) no-lever/no-water conditions. After 4 days, CER extinction continued with lever returned for all Ss. Analysis of suppression ratios indicated that water availability was the major factor differentiating groups.

At least two studies have found that lever presence during CER training results in differential suppression during CER extinction when compared with lever-absence training conditions. Wagner, Siegel, \& Fein (1967), for example, obtained a partial reinforcement effect only if the lever was present during CER training. Similarly, while Hilton (1969)

\footnotetext{
* Presented at Midwestern Piycholorical Association. Cincinnati, 1970. Bated on the senior author's IS thesis. Iastern Vichinan University: now at the Lniversity of Alabama. University. Ala. 35486 .
}

found PREs for groups trained under both lever conditions. groups given CER training with lever present exhibited greater resistance to extinction than did their lever-absent counterparts. regardless of CS duration or reinforcement schedule employed. One possible explanation for these findings is that under lever-present conditions. accidental response-shock contingencies develop.

Only one study to date has compared kever-in with lever-out conditions during CER extinction. Jackson (1970) found that if initial CER extinction was concurrent with operant responding (lever present). subsequent extinction was more advanced as compared to lever-absent conditions during initial CER extinction. Since both groups were given CER training with lever removed, there was no opportunity for response-shock contingencies to develop.

Jackson explained his results in terms of a counterconditioning mechanism. That is, reinforcement produced during early CER extinction served to inhibit the emotional response elicited during the $\mathrm{CS}$. He further suggested that the act of responding might not be necessary. That is, water reinforcement delivered independently of responding might have been just as effective. The present study, then, attempted to assess the relative roles of responding and reinforcement and provided a further test of the counterconditioning hypothesis.

SUBJECTS AND APPARATUS

The Ss were 32 male Sprague-Dawley rats weighing an average of $307 \mathrm{~g}$ at the beginning of experimentation. The experimental chambers used for barpressing, CER training, and CER extinction were two identical Foringer Skinner boxes with automatic programming equipment. They were housed in sound-attenuating, blower-ventilated enclosures isolated from both the home-cage area and the programming apparatus. Each chamber contained a removable lever and normally recessed dipper that delivered $0.1 \mathrm{cc}$ of water upon activation. The CS used throughout the experiment was a $2-\mathrm{min}$, 90-dB clicker. The US used only during CER training was a $0.5-\mathrm{sec}, 1.0-\mathrm{mA}$ scrambled shock delivered through grid floors.

\section{PROCEDURE \\ Preliminary Operant Training}

The experimental procedure was divided into four phases, the first of which was designed to produce stable operant responding on a VI 1-min schedule for water reinforcement. Upon arrival from their supplier. Ss were assigned randomly to four groups of eight animals each, and then individually housed in home cages where food (Purina Lab Chow) was available ad lib throughout the experiment. With the exceptions of the first and second days, water was available for $10 \mathrm{~min}$ daily, beginning $5 \mathrm{~min}$ after the conclusion of each daily experimental session. On the first day, water was available ad lib, and on the second, Ss were completely deprived. On the third day, Ss were magazine trained and shaped to a criterion of 40 reinforcements on a CRF schedule or $28 \mathrm{~min}$ in the chamber, whichever came first. On the next day, dipper presentations 